\title{
Entrepreneurial Behaviour of the Elderly in Poland - Chosen Aspects
}

\begin{abstract}
Matgorzata Gajowiak*
Nowadays one can observe progressive demographic changes in the form of, among others, an increasing proportion of post-working age population and lowering birth rates. The negative consequences of these changes are visible especially in the labour market. For these reasons, it is necessary to undertake efforts aimed at improving working conditions, retraining employees, as well as introducing flexible working hours in order to increase employment among older people. These activities support the implementation of the concept of age management which is becoming increasingly popular among European countries. This idea aims to allow workers, and particularly the elderly, a fuller use of their abilities, thereby increasing their motivation to work. Consequently, it seems that higher employee productivity has a positive effect on the stabilization of employment and enterprise development.
\end{abstract}

Keywords: entrepreneurship, older people.

Submitted: 31.08.16 | Accepted: 26.10.16

\section{Zachowania przedsiębiorcze osób starszych w Polsce - wybrane aspekty}

Wspótczesny świat charakteryzuje się postęującymi zmianami demograficznymi w postaci m.in. wzrostu odsetka osób w wieku poprodukcyjnym, a także niskim przyrostem naturalnym. Negatywne konsekwencje tych przemian widoczne sa w szczególności na rynku pracy. Realna groźba destabilizacji rynków pracy, funkcjonowania systemu zabezpieczenia spotecznego czy wykluczania seniorów z życia zawodowego i spotecznego oraz publicznego, przy jednoczesnym nierzadkim ich dyskryminowaniu, zmuszaja do kompleksowego podejścia do kwestii starzenia sie spoteczeństwa. Wymaga to jego uwzględnienia także w zarzadzaniu wspótczesnym przedsiębiorstwem. Z tego też powodu na znaczeniu obecnie nabiera koncepcja zarzadzania wiekiem, w której poprzez odpowiednie podejście do zarzadzania personelem $w$ organizacji upatruje się szans niwelowania negatywnych konsekwencji zachodzacych przemian demograficznych. W rezultacie stać się ona może także sposobem na wydtużenie aktywności zawodowej seniorów.

Słowa kluczowe: przedsiębiorczość, ludzie starzy.

Nadesłany: 31.08.16 | Zaakceptowany do druku: 26.10.16

JEL: J1, J4

\footnotetext{
* Małgorzata Gajowiak, PhD - Chair of Economic Sciences, Poznan University of Technology.

Correspondence address: Poznan University of Technology, Chair of Economic Sciences, Strzelecka 11 St., 60-965 Poznań; e-mail: malgorzata.gajowiak@put.poznan.pl.
} 


\section{Introduction}

The process of population ageing is a global phenomenon, although its intensity depends on the level of socio-economic development. Highly-developed countries are characterized by a higher quality of life, lower fertility, and a longer life expectancy. Thus, one can observe an increased proportion of the elderly in the population. Such communities are characterized by such attributes as "generational tsunami", "pension bomb" or "demographic crisis". The World Health Organization estimates that since 1995, every month, a million people who are minimum 60 years old have been appearing around the world, and their total number in 2025 will be 1.2 billion and 2 billion in 2050 (WHO, 2012). According to the forecasts made by the Central Statistical Office, the number of people aged $60+$ within the territory of Poland in 2035 will increase by half compared to 2008, and will amount to 9.6 million (GUS, 2009). In turn, in 2050 the population of Poland will decrease by approximately 4 million people, and the demographic dependency ratio for the elderly will increase to $60 \%$, placing Poland among the oldest countries in Europe (Herbich, 2010, p. 127).

It should be noted that due to the mentioned demographic changes, the phenomenon of labour force ageing is observed at the same time. "This situation may result in a decrease in the total number of workers, weakened incentives for investments due to limited savings, and restrictions and pressure on pension systems and state budgets" (Urbaniak et al., 2015, p. 53). What is more, the decrease in the absolute number of people able to work and the change of the structure of this population carry the risk of weakening economic growth and worsening the standard of living in each country (Nyce and Schieber, 2011). Therefore, only those countries that quickly and actively respond to the negative demographic trends have a chance to become the most competitive. This requires, above all, care for the expansion of entrepreneurial attitudes especially among the elderly. "These attitudes, translating into creative and innovative actions, may contribute to achieving both social and economic efficiency. It can be argued that nowadays investments in human capital will have a decisive influence on who will win the economic competition in global mar- kets. They are more important than e.g. labour costs, prices of raw materials or energy” (Urbaniak et al., 2015, p. 76).

Promoting entrepreneurial attitudes, expressed both through working for organizations and running own business, is necessary due to the fact that in both these fields seniors are characterized by low commitment. The average employment rate of people of pre-retirement age (55-64 years) in the European Union, amounting to $54.0 \%$, might confirm that. Thus, this means that only half of this population is considered as the real labour force (MRPiPS, 2016). Unfortunately, Poland differs significantly in this respect even from this unfavourable EU average. According to Eurostat's data, our country has one of the lowest employment rates in Europe. For people aged $55-64$, this rate was only $46.1 \%$ in 2015 (GUS, 2014). On the other hand, considering self-employment, only $5 \%$ of people aged $45 / 50+$ are active in this area (GUS, 2014).

The real threat of destabilization of the labour market necessitates adopting a comprehensive approach to the issue of ageing population and taking it into account in the management process in modern enterprises. Analyzing entrepreneurial attitudes of the elderly, the article is more devoted to the employment of older people in businesses, because, according to many studies, this population is seen by potential employers as less attractive in comparison to the younger generation (Richter-Kaźmierska and Stankiewicz, 2013, pp. 81-83). For this reason, after outlining the characteristics of seniors' activity in the labour market and their competences, the article presents the concept of age management.

\section{Entrepreneurship 50+ \\ Labour Market Statistics}

Let us note at the beginning that the term entrepreneurship is an interdisciplinary category to which many representatives of various scientific disciplines relate, including economists, sociologists, researchers in psychology, and specialists in the field of management. As a result of the large interest in this concept, literature knows a variety of attempts at its conceptualization which often put emphasis on the subjectivity, the procedural nature or the objectivity of this category. However, 
T. Kraśnik notices that "[...] entrepreneurship is a special type of human activity, acting individually or within an organization, consisting in taking advantage of opportunities emerging in the environment through the implementation of undertakings [...] that bring economic and/or non-economic effects to their entities and surroundings" (Kraśnicka, 2002, p. 14). Thus, this means that it relates to business activities of natural persons, corporate entities and other organizations, is aimed at running economic businesses both effectively and rationally, and covers activities undertaken in the social, cultural, scientific or political spheres (Duraj and Papiernik-Wojdera, 2010). It is widely accepted that entrepreneurship is the driving force responsible for the development of each company and each economy, and any shortcomings in this area have a negative impact on the welfare of the population in the long term.

Unfortunately, based on the above-mentioned definitional notion of the discussed category and focusing on people aged 50 and older, one can observe that the leve of their entrepreneurship in Poland is quite low. This applies both to people employed in companies and to those who run their own business or even work voluntarily. According to Eurostat's data, Poland is characterized by one of the lowest employment rates in Europe, but certainly the situation improved over the years 2010 2015. For people aged 55-64, this rate in 2015 was only $46.1 \%$ in our country, while the EU average amounted to $54.0 \%$. The highest levels of this rate characterize such countries as Sweden, Estonia, Germany and Denmark, and the lowest, in addition to Poland, characterize Malta, Greece and Croatia (MRPiPS, 2016). On the other hand, for people aged 50+ in Poland, the proportion of the employed in the total population over 15 years of age is only $23.6 \%$. Thus, this means that from a group of approximately 5 million people aged between 55-64, more than 3 million are outside the labour market. In turn, from a group of a total of 13 million people aged $50+$, more than 9 million people do not work (GUS, 2014).

Tomasz Schimanek believes that "such a low level of employment of $50+$ people is the result of socio-economic changes that have taken place in Poland within the last 20 years, as well as the state policy in the 1990s that was aimed at conscious suppressing the activity of people over 50 years old. That was to be a recipe for big unemployment, particularly among young people. In the first half of the 1990s, as a result of facilitating the receipt of early retirement and disability benefits, nearly 2.8 million people became entitled to such benefits, which significantly contributed to reducing the level of economic activity of the elderly but did not reduce unemployment among young people in a radical way" (Schimanek, 2010b, p. 10). Moreover, the quoted researcher adds that at the end of the 1990s, the Polish government no longer pursued its policy aimed at early professional deactivation, undertaking to make changes to the pension system. As he further concludes, "these changes and, above all, a well-balanced economy, resulted in a gradual reversal of the downward trend, and a slow increase in the employment rate of mature people" (Schimanek, 2010b, p. 10)

Moreover, most researchers associate entrepreneurship with running own company. "It is a functional approach to the entrepreneurship, connected with the process of organizing a company and its effective and efficient operation, including incurring significant risk" (Urbaniak et al., 2015, p. 77). Analyzing the data, one can observe that among the owners of companies in the year 2013, only 5\% were aged $45+$. It should be added that self-employment is, in this case, often the result of meaningful work and life experience gained during life. What is more, it is also a consequence of the lack of interest in employment of mature entrepreneurs. "The reluctance to hire older people results in them looking for work for a longer time. Therefore, setting up own business might be an alternative to that situation" (Urbaniak et al., 2015, p. 81). According to research, this form of activity is carried out most often by men (6.9\%), with women taking it up much more rarely $(2.8 \%)$. In addition, people with higher education frequently engage in this type of activity (ibid.). Interestingly, studies also show that companies run by this age group are non-progressive, although stable, employ less than the average number of people and to a lesser extent benefit from external funding (Richter-Kaźmierska and Wasilczuk, 2014, p. 155). What is more, 
P. Kubicki proves that owning a company does not realize dreams of those people, it is also not the best choice for them, but the only possible to get some money (Kubicki, 2013, p. 23).

Moreover, in addition to employment and running own business activity, labour market activities also include voluntary work, which is a kind of alternative to professional work. According to research, only $2 \%$ of Polish people aged between 18 and $59 / 64$ had been active in this area within 12 months before the study, with $1 \%$ of people over the age of 50. Compared to European statistics, Polish seniors engage in voluntary activities less often. Among the factors responsible for this state of affairs, one can mention, among others, the history, tradition and culture of old age in Poland that were shaped by the socialist system, which depreciated the role of social activity. What is more, the fact that until recently the limited possibility of public participation was observed, which was due to the perception of "senior citizens as beneficiaries of aid rather than providers of support", was important as well (Turek, 2013 , p. 87). Additionally, seniors themselves do not realize that also a retired person may be a volunteer. As they point out, their domain is rather "family volunteering", i.e. support in raising grandchildren (Osiecka-Chojancka, 2012).

\section{Knowledge, Skills, and Attitudes}

Modern economy is characterized by high dynamics of change, and due to this non-material resources, rare and difficult to imitate, are becoming meaningful. Meanwhile, the role of material factors is decreasing (Gajowiak, 2015). Strategic factors are knowledge, skills, and entrepreneurial, creative, and innovative attitudes (Urbaniak et al., 2015). "These behaviours largely determine longer periods of maintaining employment in the labour market, thereby contributing to creation of added value for the whole society" (Urbaniak et al., 2015, p. 76).

Unquestionably, entrepreneurial activity is determined by many factors, among which it is worth paying attention to human capital, including the level of education and skills. As evidenced by statistical data, it is a dimension in the case of which one can observe the greatest differentiation between successive generations of Polish people. As noted by K. Turek, "those who received formal education in the 1960s, 1970 s or 1980 s had to deal with totally different conditions, opportunities, and aspirations than young people in the 1990s and at the turn of the century" (Turek, 2013, p. 88). The socialist system that favoured vocational education played a major role in that case. Generally, it can be said that among thirty-year-old people, every third person graduated from a university, among forty-year-olds - less than every fifth, while among fifty-year-olds - only every tenth. A steady growth of interest in higher studies with simultaneous marginalization of vocational education has been observed as late as since the beginning of political transformation (Turek, 2013, pp. 88-89).

The situation is similar in the case of continuous education, participation in trainings and courses after completion of formal education. Vocational training or general education in 2012 was attended by only $1.2 \%$ of employed men and $1.8 \%$ of employed women aged 55-64. This percentage is much lower than the EU average, which is $6.4 \%$ for men and $9.9 \%$ for women. It is worth noting that the participation of older workers in vocational training or general education in Poland is the second lowest in Europe, with only Hungary in front (OECD, 2015). As suggested by the elderly themselves, the low degree of involvement in this type of training activities is mainly due to the fact that they will retire within a short period, so they treat such courses as a waste of time, and secondly, the employer's profit from this type of investment will translate into professional work to a small extent. Therefore - in their opinion - they are not profitable. This situation is further exacerbated by a low self-esteem of people in the analysed age group. As many as $84 \%$ of the unemployed in the $50+$ group are convinced of employers' negative attitude towards them, and the result is that they do not try to search for work or reskill to improve their situation in the labour market (Turek, 2013). However, one should keep in mind that "the acceleration of technological progression makes 'traditional' education require complementation, extension at a similar rate as changes in technology; therefore, it is essential to learn throughout life. As shown by numerous theoretical and empiri- 
cal research studies, investments in obtaining education, learning (improvement) in the workplace, and new technologies are closely correlated with increased productivity of work" (Urbaniak et al., 2015, p. 61).

What is more, apart from the level of education, entrepreneurial activity is undoubtedly highly influenced by other attributes of the human capital in the form of numerous skills possessed by employees. Thus, the evaluation of competences of senior citizens above 55 years of age compared to the younger generation was carried out in a survey by Eurobarometer in 2011. Survey respondents were asked to rate 12 selected features that were useful in professional work in terms of whether they could be used to characterize older people or younger people. Overall results for Poland and the EU27 are presented in the table 1.

The obtained results allow formulating a statement that older people perform well when compared to the younger generation only in terms of two features, i.e. experience and responsibility. As many as $76 \%$ of respondents indicated that people over 55 years old have more experience (Eurobarometer, 2012). It should be added that this feature is commonly recognized by researchers of gerontology as the most important productive resource at an older age. What is more, it is also indicated that even in a group of professions related to sales and trade, or call centre, mature and experienced employees got better work results thanks to patience and the mentioned experience (Schimanek, 2010a). Taking into account another feature, i.e. responsibility, $56 \%$ of respondents said that it mainly described the elderly. Both results are lower than the average for the EU27 and are at the level of $87 \%$ and $67 \%$, respectively (Eurobarometer, 2012). It should be noted that the obtained results are confirmed by the widespread

Table 1. Evaluation of selected resources and skills of older people in Poland and the EU27.

\begin{tabular}{|c|c|c|c|c|}
\hline Feature & 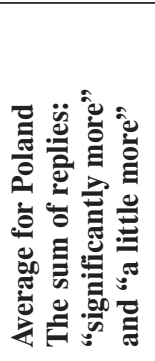 & 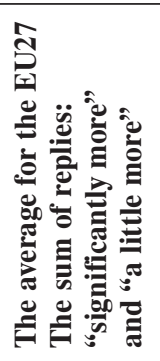 & 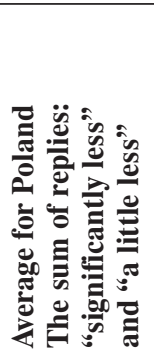 & 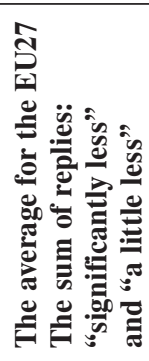 \\
\hline Experience & 76 & 87 & 3 & 3 \\
\hline Responsibility. & 56 & 67 & 3 & 3 \\
\hline Decisiveness & 46 & 64 & 11 & 7 \\
\hline Coping with stress & 39 & 52 & 18 & 18 \\
\hline The ability to solve problems & 43 & 60 & 13 & 7 \\
\hline The ability to cooperate well with others & 42 & 50 & 7 & 8 \\
\hline Dealing with people from other cultures & 32 & 37 & 16 & 21 \\
\hline Flexibility & 28 & 35 & 32 & 32 \\
\hline Productivity & 26 & 38 & 28 & 19 \\
\hline Openness to new ideas & 19 & 25 & 43 & 42 \\
\hline Creativity & 20 & 29 & 36 & 28 \\
\hline Knowledge of new technologies & 16 & 22 & 55 & 57 \\
\hline
\end{tabular}

Source: Eurobarometer, 2012, pp. 196-207. 
perception of old age as a sign of experience, knowledge, wisdom, contact with supernatural powers, blessings, authority, power, and prestige (Klimczuk, 2012).

Furthermore, $46 \%$ of survey respondents assigned another feature to the elderly, i.e. decisiveness. This result is also lower than the EU average, which is $64 \%$. In the opinion of $42 \%$ and $43 \%$ of respondents, respectively, the ability to cooperate and solve problems characterized people over 55 years of age. Unfortunately, the elderly find it more difficult to cope with stress than the younger generation $(39 \%$ of respondents assigned them this feature), they are not that good at working with people from other cultures (32\%), and are less flexible $(28 \%)$. It is worth noting that among numerous functions attributed to entrepreneurship, in particular to entrepreneurs, one can point to three key ones, i.e. taking risk and operating in conditions of uncertainty, bringing innovation, tracking changes, and adapting to or anticipating economic phenomena and processes.

In addition, only $26 \%$ of respondents are of the opinion that the elderly are more productive than young people (Eurobarometer, 2012). It is worth mentioning here that this result - as already mentioned in the previous paragraph - has its justification in the research on the health of the elderly. It is worth noting that the state of health of a mature person depends on a number of factors, including human genome, conditions of living, lifestyle, education, health care, or the condition of the working environment (Klimczuk, 2012). The elderly themselves - according to the research - considered health as one of significant barriers to undertaking work. As many as $34 \%$ of the unemployed and $86 \%$ of professionally inactive respondents aged between 50-59 and 64 complained about a bad health condition, which prevented them from undertaking professional activity in the labour market (Turek, 2013). Moreover, 20\% of entrepreneurs named the fear of reduced productivity as the reason for not employing people aged 45+ (Chłoń-Domińczak, 2010).

Older people in Poland were assessed the worst in terms of openness to new ideas (only 19\% of respondents associated this feature with people aged 55+), creativity $(20 \%)$, and knowledge of new technologies $(16 \%)$. Also in these areas one observes worse results than the EU27, although the EU average values are not high and satisfactory either (Eurobarometer, 2012).

However, the data from CBOS proves that there is a technological gap as it shows that $77 \%$ of pensioners have never used a computer or the Internet, $94 \%$ have never participated in any interesting activities, courses such as computer workshops, memory exercises, third age university classes or foreign language classes, and $92 \%$ of seniors have never improved their skills or complemented their knowledge (CBOS, 2012). As noted by Ł. Jurek, "nowadays, one should look for sources of forces in rapid technological progress that push older people out from the labour market. Innovations transform the manufacturing process and create new branches of economy. People working in modern occupations are usually young people, the so-called "pioneers of progress". They are handsomely rewarded for their work, and enjoy high social recognition. Older workers are usually hired in declining industries (e.g. heavy industry and mining). Their professional qualifications are depreciated. This group is commonly associated with outdated knowledge, technological backwardness, aversion to innovation, as well as limited abilities to acquire new skills. As a result, ageing employees are perceived as a threat to a company's competitiveness and a factor that weakens its position in the market" (Jurek, 2012, p. 141).

\section{A New Approach}

In the face of challenges posed by the phenomenon of ageing and, in particular, the low entrepreneurial spirit shown by seniors that is discussed in this article, the concept of age management, considered as an important element of the personnel policy implemented in a company, is becoming increasingly popular in many developed countries. Generally, this concept can be regarded as a specific part of diversity management, whereas age is treated here as a special feature that differentiates employed persons. In this case, age management is expressed by carrying out "activities adapted to preferences, needs and possibilities of workers of all ages within the company, which allow using the potential of the company's human resources in a rational and effec- 
tive way" (Liwiński and Sztanderska, 2013, p. 6). Therefore, this definition emphasizes that this idea is aimed at all employees, and not only at the elderly. Enterprises should take preventive measures that should be spread out over the entire career of an employee (i.e. life course approach) due to their long-term influence on the ability to work professionally through, among others, health promotion, prevention of various diseases, organization of training, and provision of equipment for work posts. However - importantly - in the face of current demographic problems, the concentration of attention mainly on $50+$ people must not have pejorative connotations that would discriminate against younger people, and should be aimed to increase the professional activity of older people and fully use the potential of people who still, in spite of old age, are active in the labour market (Liwiński and Sztanderska, 2013).

To implement the ideas of age management in business conducting practices, it becomes necessary to take measures to increase work productivity, in particular of the elderly, in the form of, among others, the following (Lojkowska and Kędziora, 2010, pp. 13-15):

- planning employment and recruitment of new employees;

- carrying out training and planning a career development path;

- designing workstations, and internal transfers between work posts;

- implementing flexible forms of employment and modernization of work;

- health protection and promotion;

- termination of employment and retirement.

On the basis of reviews of not only literature sources but business research as well, it should be added that the implementation of the age management concept into management practice can bring many benefits in the following forms:

1. access to new human resources, because - as has already been mentioned in this article - older people are a kind of a treasury of knowledge and wisdom obtained in the course of a lifetime and experience, which can positively influence the development of a stable organization (Klimczuk, 2012, p. 29);

2. improvement of the company's image in the eyes of other employees by increasing their loyalty and commit- ment "by presenting a vision of stable work, opportunity to develop and a long professional activity. It can also significantly reduce training costs thanks to the introduction of internal training and monitoring programmes" (Turek, 2013, p. 102);

3 . building the image of a socially responsible company which is open to the elderly, is not influenced by common stereotypes concerning old age, and does not discriminate based on age (Kojkowska and Kędziora, 2010, p. 4);

4. increasing the trust of older clients, which - as noted by T. Schimanek - is important for employers since older clients prefer to be served by their peers. What is more, employers make use of the fact that regardless of the age of clients, there are professions in which age is an asset, because it inspires trust in clients" (Schimanek, 2010a, p. 43);

5. increased innovation, because "diversity contributes to creativity. People with different life experiences bring new ideas to the company and inspire each other" (Liwiński and Sztanderska, 2013, p. 5); 6. increased loyalty as people aged $50+$ decide to change their place of employment less often than younger people, because they value stability over change (Liwiński and Sztanderska, 2013, p. 8);

7. increased level of social or public participation (Gajowiak, 2014, p. 297);

8. national product growth (Lojkowska and Kędziora, 2010, p. 4);

9. decreased financial burden on the state budget for payment of social benefits (Liwiński and Sztanderska, 2013, p. 6).

\section{Age Management - Still a Challenge for Polish Business}

It should be emphasized that the first activities aimed at promoting the concept of age management were undertaken in the early 1990s in Western Europe. Among countries which have their own practical achievements, there are, for example, Austria, Belgium, and Finland (Karpowicz, 2010, pp. 42-44). In Poland, in turn, this idea started to function around 2008, and thanks to projects financed from the budget of the European Union, it is becoming more popular.

Many interesting results related to the concept of age management are provided 
by a research study on evaluation of implementation of this strategy conducted by PARP in 2009-2013 on a group of 72 Polish companies. It turns out that the main motive for implementation of age management systems in Poland was not the threat posed by a sudden reduction in the labour force in the next few years. The lack of this type of insecurity was due to the fact that the following demographic changes are spread out over time (within the next 20 years), which limits companies' motivation to immediately implement the abovementioned systems. Moreover, it turns out that mainly small businesses, particularly in the face of the ongoing economic crisis, are not as eager and willing to implement age management concepts in practice, as such companies have no guarantee of operation and functioning in distant future. On the other hand, Polish entrepreneurs are motivated to implement this concept by the problem associated with the functioning of employees of different ages in organizations. And so, employers include the following as reasons for increased interest in age management (Liwiński and Sztanderska, 2013, pp. 14-15):

1. risk of knowledge loss related to retirement of older employees;

2. reluctance of older employees to share their knowledge with younger people;

3 . difficulties in managing the much younger generation reported by older managers;

4. older employees' opposition to changes in work methods;

5. lack of willingness to develop shown by a certain group of older employees;

6. lack of suitably qualified candidates for work;

7. high turnover of younger employees;

8. difficulties in ensuring proper conditions of work that would allow for further continuation of work in positions where there is high arduousness of tasks or strict health requirements (due to the increased statutory retirement age);

9. low motivation of the elderly to achieve great results at work if the salary depends on their position and their competence, and not on seniority.

What is more, on the basis of the quoted research, in Polish companies one can also point to numerous barriers which, in the opinion of business owners, make it difficult or even impossible to effectively implement the basic guidelines of the age management concept into management practice. Therefore, the most frequently quoted ones include (Liwiński and Sztanderska, 2013, p. 15):

- no tradition related to human resource management in enterprises;

- lack of knowledge and training for managers in effective human resource management techniques, especially in the context of key features, i.e. age;

- stereotypes concerning both younger and older people that are widely copied in Poland, and consequently taking schematic actions by employers on their basis;

- the rooted belief that older people should quickly leave the labour market thus giving the younger generation a chance to start professional work, which is often observed in periods characterized by a high unemployment rate;

- employers' fear of a possible abuse of protection against firing by the elderly of the retirement age, and - as a consequence of this privilege - probability of lower labour productivity among the privileged;

- much lower employment costs of students who are not 26 years of age yet;

- difficulty in reconciling work and family responsibilities with taking care of health, which becomes particularly important in older employees;

- the strong belief of the elderly that preretirement age is a period of "preparation for retirement", which potentially reduces their diligence, but also reduces their chances to participate in additional trainings organized by employers.

The afore-mentioned barriers have a huge impact on the lack of interest in implementing the idea of age management that is noticeable among Polish entrepreneurs. There are few examples of the socalled "good practices" which relate mainly to large companies, mostly with foreign capital. In their case, the implementation of the mentioned concept is of an imitative nature and takes place in accordance with the already completed scheme of implementations in foreign seats. Moreover, "companies are not interested in age management goals and techniques, thus demonstrating their experience gained within recent years when the demographic, educational and regulatory situation has 
been hardly conducive to employment of older people. This is because recent years have brought considerable rejuvenation of the working-age population. Baby boomers (i.e. the echo of the post-war baby boom) entered the labour market, and many young job candidates were available - the number of people aged 18-34 increased in $2000-2008$ by approximately 800,000 people. At the same time, people between 25 and 34 years of age are employees showing a high level of professional activity" (Liwiński and Sztanderska, 2013, p. 16).

In the face of the low popularity of the age management idea in Poland, the government authorities adopted its basic content in a document entitled "Assumptions of Long-Term Senior Policy in Poland for the years 2014-2020". According to this document, the goals of the senior policy include the issue of creating friendly working conditions for employees and using solutions in the field of age management. The basic recommendations of the government in this regard include as follows:

- adapting the pace of work to the elderly, implementing a flexible working time, and analysing the possibility of taking work leave to raise qualifications, leaving shift work and increasing the importance of preliminary and periodic tests for employees;

- providing a possibility to decide on the order of tasks, break time at work, and a clear definition of roles and career prospects for the employed elderly;

- limiting hard work of a physical nature and work in adverse conditions (e.g. low and very high temperatures);

- modifying human resource management to make use of the strengths of older workers;

- initiating actions aimed at promoting a positive attitude towards mature people in society;

- enabling professional development and career at any age (Rada Ministrów, 2014). It should be emphasized that the authors of the government document stress that efforts undertaken to implement the guidelines of the age management concept should be taken both by government institutions, NGOs, and private sector companies. This is why it becomes necessary to create and implement mechanisms of regular cooperation between employers, public and government entities, as well as promote public consultations with people above 50 years of age in taking actions to extend their activity period in the labour market (Rada Ministrów, 2014).

\section{Conclusion}

Currently, developed countries experience the process of a demographic transformation. As indicated by Ł. Jurek, "throughout one century (from the midtwentieth century to the mid-twenty-first century), the structure of population went from a progressive model, through stagnant, to a regressive model. If current trends are maintained, an ultra-regressive structure will be formed and consolidated and it will be described as the inverted demographic pyramid' [...] Older people are beginning to dominate numerically over the rest of the population, particularly over the youth" (Jurek, 2012, p. 34). This state brings numerous economic and social consequences. The process of population ageing is clearly related to the ageing of the labour force. At the moment, in the EU countries one can observe a low level of economic activity and employment among the $50+$ population when compared to the younger generation. According to estimates of the European Commission, the process of population ageing will be primarily responsible for the decline in economic growth of the EU from the level of 2-2.5\% (2003) to approximately $1.25 \%$ in 2040 . What is more, there are societies (Spain, Poland, and Greece) where the tendency to retire early is strongly perpetuated.

For this reason, there is an urgent need for the activation of entrepreneurial potential that lies in persons aged $50+$. The idea of active ageing is enshrined permanently in the development strategies of the European Union. Therefore, the challenge for its individual members is to create incentives for active ageing, through ensuring that seniors play the role of both owners of businesses and employees. "Thanks to the entrepreneurial behaviours of the elderly, more companies could be run, and the multiplier effect would imply investment and manufacturing processes in other entities of the economy. Activity, knowledge and experience of older people as advisers in new and developing enterprises could also be used to a greater extent" (Urbaniak et al., 2015, p. 87). 
In this article, more attention was paid to the issue of employment of people aged $50+$. It is obvious that the desire to increase labour market participation requires the development of a comprehensive approach to the management of modern enterprise. And so, more and more representatives of organization science and management, economics, social policy, and psychology, as well as the public sphere focus their discussion on the concept of age management This idea represents a modern approach to personnel management at different ages, emphasizing that every company must adapt to the needs, preferences and capabilities of employees of different ages. These steps will enable the rational but also - which is equally important - effective use of labour resources. Among the major areas around which this concept focuses, one can distinguish: lifelong learning, the development of career paths, flexible forms of employment, promotion and protection of health, as well as transfers between workplaces and the motivation.

\section{References}

CBOS (2012). Komunikat z Badań nr BS/106/2012 "Sposoby spędzania czasu na emeryturze". Warszawa: CBOS.

Chłoń-Domińczak, A. (2010). Ekonomiczne skutki i uwarunkowania aktywności zawodowej osób 50+ w Polsce. In: Zarzadzanie wiekiem i nie tylko. Warszawa: Akademia Rozwoju Filantropii w Polsce.

Duraj, J. and Papiernik-Wojdera, M. (2010). Przedsiębiorczość i innowacyjność. Warszawa: Difin.

Eurobarometer (2012). Active ageing report. Brussels: European Commission.

Gajowiak, M. (2015). Asset sources of competitive advantage of SMEs From high-tech sector in the region of Greater Poland. Quarterly Journal Oeconomica Copernicana, 6(4), http://dx.doi. org/10.12775/OeC.2015.030

Gajowiak, M. (2014). Causes and consequences of low employment activity of seniors - Selected aspects. In: Social security systems against the challenges of demographics and market. Poznań: Wydawnictwo Politechniki Poznańskiej.

GUS (2009). Prognoza ludności na lata 2008-2035. Warszawa: GUS.

GUS (2014). Sytuacja demograficzna osób starszych $i$ konsekwencje starzenia się ludności Polski w świetle prognozy na lata 2014-2015. Warszawa: Główny Urzad Statystyczny. Retreived from: www. stat.gov. pl (12.08.2016).
Herbich, M. (2010). Diagnoza, analiza i symulacja wariantowa możliwych ubezpieczeniowych form dobrowolnych programów emerytalnych na rynku pracy. Warszawa: Polska Izba Ubezpieczeń.

Jurek, Ł. (2012). Ekonomia starzejącego się spoteczeństwa. Warszawa: Difin.

Karpowicz, E. (2010). Kompleksowy program aktywizacji osób starszych 50+. Warszawa: Wydawnictwo Akademii Leona Koźmińskiego.

Klimczuk, A. (2012). Kapitat spoteczny ludzi starych na przykładzie miasta Biatystok. Warszawa: Wydawnictwo Wiedza i Edukacja.

Kraśnicka, T. (2002). Wokół pojęcia przedsiębiorczości. Przegląd Organizacji, 66.

Kubicki, P. (2013). Przedsiębiorczość osób w wieku $50+$ - perspektywy i bariery. Polityka Spoteczna, 1, p. 23.

Liwiński, J. and Sztanderska, U. (2013). Standardy zarzadzania wiekiem $w$ organizacjach. Warszawa: PARP, Uniwersytet Warszawski.

Łojkowska, M. and Kędziora, K. (2011). Zarządzanie wiekiem $w$ pytaniach $i$ odpowiedziach. Warszawa: Stowarzyszenie Interwencji Prawnej.

MRPiPS (2016). Osoby powyżej 50. roku życia na rynku pracy w 2015 roku. Warszawa: Ministerstwo Rodziny, Pracy i Polityki Społecznej, Departament Rynku Pracy, Wydział Analiz i Statystyki. Retrieved from: https://www.mpips.gov.pl/analizy-i-raporty/ raporty-sprawozdania/rynek-pracy/sobypowyej50rokuycianarynkupracy/rok-2015/ (29.08.2016).

Nyce, S.A. and Schieber, S.J. (2011). Ekonomiczne konsekwencje starzenia sie spoteczeństw. Warszawa: Wydawnictwo Naukowe PWN.

OECD (2015). Starzenie się i polityka zatrudnienia. Polska 2015. Lepsza praca wraz $z$ wiekiem. New York: OECD.

Osiecka-Chojnacka, J. (2012). Spoteczne opinie o starości a wdrażanie idei aktywnego starzenia się. Studia BAS, 2.

Rada Ministrów (2014). Założenia długofalowej polityki senioralnej $w$ Polsce. Uchwała nr 238 Rady Ministrów RP z dnia 24 grudnia 2013 r. Warszawa: Rada Ministrów.

Schimanek, T. (2010a). Co to jest zarzadzanie wiekiem? In: Zarzadzanie wiekiem i nie tylko. Warszawa: Akademia Rozwoju Filantropii w Polsce.

Schimanek, T. (2010b). Społeczne uwarunkowania i konsekwencje niskiej aktywności zawodowej osób 50+ oraz rozwiązania służące jej zwiększeniu.

In: Zarzadzanie wiekiem i nie tylko. Warszawa: Akademia Rozwoju Filantropii w Polsce.

Straś-Romanowska, M. (2007). Późna dorosłość. Wiek starzenia się. In: B. Harwas-Napierała and J. Trempała (eds.), Psychologia rozwoju człowieka (pp. 263-292). Warszawa: Wydawnictwo Naukowe PWN. 
Turek, K. (2013). Starzenie się ludności jako wyzwanie dla gospodarki, rynku pracy, polityki i obywateli. In: J. Górniak (ed.), Młodość czy doświadczenie? Kapi tat ludzki w Polsce. Raport podsumowujacy III edycje badań BKL z 2012 roku. Warszawa: PARP.

Urbaniak, B., Gładzicka-Janowska, A., Żyra, J., Kaliszczak, L., Piekutowska, A., Rollnik-Sadow- ska, E., Sobolewska-Poniedziałek, E., Niewiadomska, A. and Gagacka, M. (2015). Socjoekonomika starzenia się wspótczesnych spoteczeństw. Warszawa: $\mathrm{CeDeWu}$

WHO (2012). Our world is changing. Geneva: WHO.

Retrieved from: http://www.who.int/world-healthday/2012/toolkit/background/en/ (20.03.2014). 